\title{
HEMAGgLUTINATING PROPERTIES OF SALMONELLA ENTERICA SEROVAR ENTERITIDIS ISOLATED FROM DIFFERENT SOURCES
}

\author{
Jane M.G. Mikchaㅜ; Antonio J. Piantino Ferreira ${ }^{2 *}$; Claudete S. Astolfi Ferreira² ${ }^{2}$ Tomomasa Yano $^{3}$ \\ ${ }^{1}$ Departamento de Análises Clínicas, Universidade Estadual de Maringá, Maringá, PR, Brasil; ${ }^{2}$ Departamento de Patologia, \\ Faculdade de Medicina Veterinária e Zootecnia, Universidade de São Paulo, São Paulo, SP, Brasil; ${ }^{3}$ Departamento de \\ Microbiologia e Imunologia, Instituto de Biologia, Universidade Estadual de Campinas, Campinas, SP, Brasil.
}

Submitted: January 29, 2003; Returned to authors: December 04, 2003; Approved: March 15, 2004.

\begin{abstract}
Twenty-five strains of Salmonella enterica serovar Enteritidis isolated from different sources were examined for hemagglutinating activity. Bacteria cultured in different media induced hemagglutination of human erythrocytes, but no reaction was observed with erythrocytes from other animal species. The hemagglutinating expression activity was better for cultures on CFA agar at $37^{\circ} \mathrm{C}$ than other conditions examined. The hemagglutination was inhibited by D-mannose, D-mannitol, melibiose, D-raffinose, L-rhamnose and sucrose. The absence of cell-surface appendages in electron microscope examinations suggested a nonfimbrial hemagglutinin. The data suggest that Salmonella Enteritidis produces nonfimbrial mannose-sensitive hemagglutinin, specific for human erythrocytes, which could be extracted in soluble form.
\end{abstract}

Key words: Salmonella Enteritidis, hemagglutinating activity, mannose-sensitive hemagglutinin, nonfimbrial hemagglutinin

\section{INTRODUCTION}

Salmonella species infect a wide range of hosts including humans and can cause disease ranging from severe enteric fever to self-limiting gastroenteritis that, in some individuals, can become systemic and life-threatening (17). The incidence of food poisoning by Salmonella spp. has been increasing in various parts of the world and foods of animal origin continue to be the major factors responsible, among them chicken meat, eggs and derivatives. Since the mid 1980s, there was a dramatic increase of food-borne salmonellosis outbreaks caused by Salmonella enterica serovar Enteritidis $(23,25)$. This disease has an important economic impact since it can affect human health and general food chain.

Relatively little information is available on the mechanisms of pathogenesis of Salmonella spp., although adherence to host intestinal surfaces is recognized as an important initial step in Salmonella infections. This interaction depends upon bacterial adhesins which recognize specific glycoconjugate receptors on the host cell surface $(4,15)$. These bacterial structures may also cause agglutination of erythrocytes of different species of animals. Such hemagglutination reactions have been designated mannose-sensitive or resistant, depending whether D-mannose or its derivatives inhibit the hemagglutination reaction (13). Since the erythrocytes posses different receptors, the bacteriaerythrocyte interaction gives a clue as to the nature of the receptors for these pathogens in the intestinal mucosa (13). For many intestinal bacterial pathogens, a correlation between hemagglutinating ability and adhesiveness has been shown $(11,13,15)$.

Fimbrial and nonfimbrial hemagglutinins have been described in Salmonella spp. Salmonella enterica serovar Enteritidis produces several types of fimbrial adhesins, including SEF14, SEF17, SEF21, long polar fimbriae (LPF) and plasmid-encoded fimbriae (PEF) (4). Their roles in infection have been studied, but their functions are still poorly understood. However, some *Corresponding author. Mailing address: Departamento de Patologia, Faculdade de Medicina Veterinária e Zootecnia, USP, Av. Prof. Dr. Orlando
Marques de Paiva, 87. 05508-900, São Paulo, Brasil. Tel.: (+5511) 30917706. Fax: (+5511) 30917829. E-mail: ajpferr@usp.br 
evidence indicates that they may be involved in the colonization and adherence of the organism to specific host tissues in the early stages of infection (9).

Whereas several fimbrial hemagglutinins have been characterized and associated with adhesion and pathogenicity, little is known about nonfimbrial hemagglutinins in Salmonella spp. Jones and Richardson (14) described a nonfimbrial mannose-resistant hemagglutinin in $S$. Typhimurium that was responsible for adhesion to and invasion of HeLa cells. Nonfimbrial mannose-resistant hemagglutinins have also been described in $S$. Typhimurium and $S$. Dublin, however they were not involved in adhesion to either HeLa or HEp-2 cells $(19,26)$.

In this study, we presented some hemagglutinating properties of Salmonella enterica serovar Enteritidis strains isolated from different sources.

\section{MATERIALS AND METHODS}

\section{Bacterial strains and culture conditions}

The twenty five strains of Salmonella enterica serovar Enteritidis used in this study were obtained from food, animal feed, animals and humans (Table 1).

The bacteria were grown on various solid and liquid media at $16^{\circ} \mathrm{C}$ and $37^{\circ} \mathrm{C}$ to determine the conditions for optimal expression of hemagglutinating activity. These media included brain heart infusion (BHI), colonization factor antigen (CFA), casaminoacids yeast extract (CYE), Luria-Bertani (LB), minimal medium (MM), phosphate buffered agar (PBA) and phosphate buffered broth (PBB), trypticase soy agar (TSA) and trypticase soy broth (TSB). Growth on solid media involved incubation at $16^{\circ} \mathrm{C}$ for $72 \mathrm{~h}$ and at $37^{\circ} \mathrm{C}$ for $18 \mathrm{~h}$. Cultures in liquid media were incubated at $16^{\circ} \mathrm{C}$ and at $37^{\circ} \mathrm{C}$ and subcultured every $24 \mathrm{~h}$ for four days, with hemagglutination activity being tested each day.

Strain SA 183, isolated from a human foodborne infection, was chosen for further studies because when grown on CFA agar, the bacteria consistently expressed hamagglutinating activity.

Unless otherwise stated, the test strain was cultivated on CFA agar and incubated at $37^{\circ} \mathrm{C}$ for $18 \mathrm{~h}$ prior to use.

\section{Hemagglutination assays}

Hemagglutination (HA) assays were carried out with erythrocytes of horse, sheep, cow, guinea pig, chicken and human phenotype $\mathrm{O}^{+} \mathrm{D}^{+} \mathrm{C}^{\mathrm{w}-} \mathrm{C}^{+} \mathrm{c}^{+} \mathrm{E}^{-} \mathrm{e}^{+} \mathrm{K}^{+} \mathrm{k}^{+} \mathrm{Kp}\left(\mathrm{a}^{-} \mathrm{b}^{+}\right) \mathrm{Jk}\left(\mathrm{a}^{+} \mathrm{b}^{-}\right)$ $\mathrm{P}_{1}+\mathrm{Le}\left(\mathrm{a}^{-} \mathrm{b}^{-}\right) \mathrm{Lu}\left(\mathrm{a}^{-} \mathrm{b}^{+}\right) \mathrm{M}+\mathrm{N}+\mathrm{S}+\mathrm{s}+\mathrm{Fy}\left(\mathrm{a}^{+} \mathrm{b}^{+}\right)$or phenotype $\mathrm{A}^{+} \mathrm{D}^{-}$ $\mathrm{C}^{\mathrm{w}-} \mathrm{C}^{+} \mathrm{c}^{+} \mathrm{E}^{-} \mathrm{e}^{+} \mathrm{K}^{-} \mathrm{k}^{+} \mathrm{Kp}\left(\mathrm{a}^{-} \mathrm{b}^{+}\right) \mathrm{Jk}\left(\mathrm{a}^{+} \mathrm{b}^{+}\right) \mathrm{P}_{1}+\mathrm{Le}\left(\mathrm{a}^{-} \mathrm{b}^{+}\right) \mathrm{L}\left(\mathrm{a}^{-} \mathrm{b}^{+}\right) \mathrm{M}+\mathrm{N}-$ $\mathrm{S}+\mathrm{s}-\mathrm{Fy}\left(\mathrm{a}^{+} \mathrm{b}^{+}\right)$. Bacteria were harvested and suspended in 10 $\mathrm{mM}$ phosphate buffered saline (PBS) $\mathrm{pH} 7.2$ to yield approximately $10^{9}$ bacteria per $\mathrm{ml}$. The bacterial suspension and the crude hemagglutinin $(100 \mathrm{ml})$ (see below) was serially diluted twofold with PBS in a 96-well U-bottomed microtiter plate, followed by incubation with an equal volume of a $1 \%$ suspension of erythrocytes in PBS for $2 \mathrm{~h}$ at $4^{\circ} \mathrm{C}$. The HA titers were recorded as the reciprocal of the highest dilution of bacteria or crude hemagglutinin yielding visible agglutination. Titers higher than four were considered positive.

\section{Carbohydrate inhibition of hemagglutination}

The inhibitory effect of sugars on hemagglutinating activity was determined using human erythrocytes as described above. Fifty microliters of a $1 \%$ erythrocyte suspension containing $1 \%$ sugar was added to $50 \mathrm{ml}$ of serially diluted crude hemagglutinin. In another test crude hemagglutinin was added to $10 \mathrm{mM}$ PBS $\mathrm{pH} 7.2$, containing $1 \%$ sugar followed by incubation at room temperature for $30 \mathrm{~min}$. After the addition of erythrocytes (1\% suspension), the plates were again incubated and the hemagglutination recorded as described above. The sugars tested were adonitol, D-arabinose, D-cellobiose, D-fructose, Dgalactose, D-glucose, lactose, D-mannitol, D-mannose, maltose, L-rhamnose, D-raffinose, D-sorbitol, sucrose, D-trehalose and D-xylose.

\section{Preparation of cell-free hemagglutinating supernatant}

S. Enteritidis (strain SA 183) grown on CFA agar at $37^{\circ} \mathrm{C}$ for $18 \mathrm{~h}$ were harvested in $10 \mathrm{mM}$ PBS, pH 7.2, and crude hemagglutinin was obtained by gentle shaking according to Camargo et al. (5). The supernatant and the pellet obtained by centrifugation $(10,000 \mathrm{x} \mathrm{g}, 30 \mathrm{~min})$ were tested for HA by the microtiter assay. The supernatant with hemagglutinating activity was filtered through a $0.45 \mathrm{~mm}$ membrane, dialyzed against deionized water for $48 \mathrm{~h}$ and designated crude hemagglutinin.

\section{Electron microscopy}

S. Enteritidis (strain SA 183) grown on CFA agar at $37^{\circ} \mathrm{C}$ for $18 \mathrm{~h}$ was deposited on Formvar-coated copper grids (400 mesh), then negatively stained with $1 \%$ ammonium molybdate and examined with a LEO-EM906 transmission electron microscope operated at $60 \mathrm{kV}$.

\section{RESULTS AND DISCUSSION}

Adherence is an important initial event in bacterial pathogenicity. Pathogenic bacteria usually develop surface structures whose primary function is interaction with receptors in the membranes of target cells, but may also cause agglutination of erythrocytes of particular animal species. This interaction with erythrocytes reflects the presence of surface structures with a role in adherence to epithelial cells that may be essential to the progress of an infection $(11,13,15)$.

The $25 S$. Enteritidis strains tested were able to agglutinate human erythrocytes and this effect was not observed with erythrocytes from other species. Hemagglutinins specific for human erythrocytes have also been described previously in Escherichia coli $(32,34)$. In addition, Salmonella strains able 
to agglutinate erythrocytes from a range of animals, or which show only weak hemagglutination of human erythrocytes have been reported $(2,3)$.

The optimum culture medium for the expression of hemagglutinating activity was CFA agar, while hemagglutinin were poorly expressed in MM and CYE agar. Most strains showed hemagglutinating activity when cultivated in BHI, LB, PBA and TSA (Table 1). These results agree with previous studies on the expression of Salmonella adhesins which concluded that CFA was the most suitable medium for expression of colonization factors $(7,24,33)$.

When Salmonella strains were grown on several solid media they agglutinated human red blood cells, but no reaction was observed when the bacteria were grown in liquid media, even after serial subculturing. Growth on solid media promotes the expression of mannose-resistant hemagglutinin but diminishes the expression of mannose-sensitive hemagglutinin, whereas cultures in broth produce mannose-sensitive hemagglutinins (13). In the present study, the best production of mannosesensitive hemagglutinin was obtained when the strains were cultivated on solid media.

The differences in hemagglutinin production between brothand agar-grown cultures suggested that surface contact was important in regulating of the expression of hemagglutinins. Other studies have shown that the expression of $S$. Enteritidis adhesins is enhanced by growth on agar surfaces, indicating

Table 1. Mannose-sensitive hemagglutination (MSHA) of human erythrocytes by Salmonella Enteritidis cultured in different solid media.

\begin{tabular}{|c|c|c|c|c|c|c|c|c|c|c|c|c|c|c|c|}
\hline \multirow{3}{*}{$\begin{array}{c}\text { Strain } \\
\text { Designation }\end{array}$} & \multirow{3}{*}{ Origin } & \multicolumn{14}{|c|}{ MSHA $*$ / culture medium /temperature } \\
\hline & & \multicolumn{2}{|c|}{$\mathrm{BHI}$} & \multicolumn{2}{|c|}{ CFA } & \multicolumn{2}{|c|}{ CYE } & \multicolumn{2}{|c|}{ LB } & \multicolumn{2}{|c|}{ TSA } & \multicolumn{2}{|c|}{ MM } & \multicolumn{2}{|c|}{ PBA } \\
\hline & & $16^{\circ} \mathrm{C}$ & $37^{\circ} \mathrm{C}$ & $16^{\circ} \mathrm{C}$ & $37^{\circ} \mathrm{C}$ & $16^{\circ} \mathrm{C}$ & $37^{\circ} \mathrm{C}$ & $16^{\circ} \mathrm{C}$ & $37^{\circ} \mathrm{C}$ & $16^{\circ} \mathrm{C}$ & $37^{\circ} \mathrm{C}$ & $16^{\circ} \mathrm{C}$ & $37^{\circ} \mathrm{C}$ & $16^{\circ} \mathrm{C}$ & $37^{\circ} \mathrm{C}$ \\
\hline SA 101 & Chicken & - & - & - & 512 & - & 16 & - & 32 & - & 16 & - & - & - & 256 \\
\hline SA 109 & Chicken & - & 16 & - & 256 & - & 32 & - & 256 & - & 64 & - & - & - & 128 \\
\hline SA 163 & Chicken & - & 32 & - & 512 & - & - & - & 16 & - & 32 & - & - & - & 512 \\
\hline SA 164 & Chicken & - & 32 & - & 128 & - & - & 64 & 64 & - & 8 & - & - & - & - \\
\hline SA 166 & Chicken & 16 & 32 & - & 512 & - & - & - & 64 & 16 & 32 & - & - & - & 512 \\
\hline SA 177 & Chicken & 8 & 64 & - & 256 & - & 32 & 128 & 256 & - & 32 & - & - & - & 256 \\
\hline SA 186 & Chicken & - & - & - & 32 & - & - & 16 & 32 & - & - & - & - & - & 32 \\
\hline SA 189 & Chicken & - & - & - & 256 & - & - & 32 & 128 & - & 32 & - & 64 & - & 512 \\
\hline SA 200 & Chicken & - & - & - & 256 & - & - & 32 & 32 & 8 & 16 & - & - & - & 32 \\
\hline SA 212 & Chicken & - & 8 & - & 256 & - & - & 128 & 256 & 8 & 128 & 8 & 64 & - & 256 \\
\hline SA 213 & Chicken & - & 64 & - & 256 & - & - & 8 & 16 & 8 & 16 & - & 16 & - & 32 \\
\hline SA 242 & Chicken & 8 & 32 & 8 & 512 & - & - & 64 & 64 & - & 16 & - & - & - & 256 \\
\hline SA 436 & Chicken & - & 128 & 16 & 256 & - & - & 16 & 32 & 8 & 16 & 16 & 64 & 8 & 256 \\
\hline SA 054 & Chicken & 32 & 64 & 8 & 256 & 32 & 64 & 8 & 256 & - & 8 & - & - & - & 32 \\
\hline SA 232 & Egg & 8 & 16 & - & 32 & - & - & 16 & 16 & - & 16 & - & - & - & 32 \\
\hline SA 108 & Feed & - & 8 & - & 256 & - & 32 & 32 & 32 & - & 64 & - & - & - & 256 \\
\hline SA 150 & Feed & - & 128 & - & 256 & - & - & 8 & 8 & - & 16 & - & - & - & 32 \\
\hline SA 145 & Food & - & - & 32 & 64 & - & - & 16 & 16 & 8 & 16 & - & - & 8 & 32 \\
\hline SA091 & Human & 16 & 32 & 32 & 256 & - & 32 & 128 & 256 & 8 & 64 & - & - & - & 32 \\
\hline SA 103 & Human & - & 32 & - & 256 & - & 256 & 32 & 256 & - & 16 & - & - & - & 128 \\
\hline SA 104 & Human & - & 32 & - & 256 & - & 256 & 32 & 256 & - & 32 & - & - & - & 128 \\
\hline SA 183 & Human & 16 & 128 & - & 1024 & - & - & 16 & 256 & 8 & 16 & 8 & 64 & - & 32 \\
\hline SA 153 & Pig & - & 16 & - & 256 & - & 32 & 32 & 64 & - & 64 & - & - & - & 64 \\
\hline SA 155 & Pig & - & - & - & 512 & - & - & - & 256 & - & 32 & - & 64 & - & 256 \\
\hline SA 235 & Pig & - & 32 & - & 512 & 32 & 64 & 64 & 128 & - & 16 & - & - & - & - \\
\hline \multirow{2}{*}{\multicolumn{2}{|c|}{$\begin{array}{l}\text { Total positive } \\
\text { Total negative }\end{array}$}} & 7 & 19 & 5 & 25 & 2 & 10 & 20 & 25 & 8 & 24 & 3 & 6 & 2 & 23 \\
\hline & & 18 & 6 & 20 & 0 & 23 & 15 & 5 & 0 & 17 & 1 & 22 & 19 & 23 & 2 \\
\hline
\end{tabular}

*Values are the reciprocals of the highest dilutions at which hemagglutination was detectable. 
that surface contact is an environmental signal for fimbrial expression (29,31). Contact between Salmonella spp. and host cells appears to be important in salmonellosis. Many of invasion-associated genes of $S$. Typhimurium are expressed only after the bacteria has already established intimate contact with the host cell (27). Type III secretion system, important in the invasion process, is triggered when the pathogen comes in close contact with host cells (6). Inv J protein and surface appendages (invasomes), required for bacterial internalization, are induced upon contact with epithelial cells $(12,35)$.

The expression of hemagglutinating activity was better for cultures at $37^{\circ} \mathrm{C}$ than those at $16^{\circ} \mathrm{C}$. Strains grown at $16^{\circ} \mathrm{C}$ showed decreased mannose-sensitive hemagglutination compared with those grown at $37^{\circ} \mathrm{C}$ (Table 1$)$. These results agree with previous reports on the expression of Salmonella hemagglutinins $(7,14,24,31)$.

The expression of hemagglutinating activity by $S$. Enteritidis was highly dependent on the culture conditions, already observed for Salmonella serotypes and other gram-negative bacteria $(11,24,29,31)$. Thus, the correct choice of conditions for bacterial growth is important when evaluating the capacity for hemagglutination.

Regarding inhibition of hemagglutinating activity by sugars, the activity was observed only in the absence of D-mannose and this effect was not observed in the presence of this sugar, suggesting the sole presence of mannose-sensitive hemagglutinins. D-mannitol, melibiose, D-raffinose, L-rhamnose and sucrose (1\%) also inhibited the hemagglutination, whereas adonitol, D-arabinose, D-cellobiose, D-fructose, D-galactose, D-glucose, lactose, maltose, D-sorbitol, D-trehalose and Dxylose did not. These observations confirmed some of the previous findings reported for Salmonella, although the inhibition by certain sugars differed from that reported in other studies $(10,16,18)$. Presumably, the sugars that inhibited hemagglutination resemble or are identical to residues available for binding to adhesins on mammalian cell membranes.

In the present study hemagglutination activity produced by $S$. Enteritidis strain SA 183 was detected in cell-free culture supernatant after gentle agitation and centrifugation. Moreover, it was observed that washing bacteria with PBS inhibited hemagglutinating activity (data not shown). These findings indicate either that the mannose-sensitive hemagglutinin produced by $S$. Enteritidis is not firmly bound to the cell, or that an unidentified secretion mechanism may be involved. Tavendale et al. (26) and Old and Tavendale (19) described hemaglutinins produced by $S$. Typhimurium and $S$. Dublin that were not associated with bacterial cells, but could be detected in the supernatant.

Ultrastructural analysis of the hemagglutinating strain SA 183 by negative staining revealed no fimbria-like filamentous structures on the bacterial surface, suggesting that the hemagglutinin produced by this strain is not related to a fimbrial structure, which are usually characterized by a filamentous structure $(11,15)$. Nonfimbrial soluble hemagglutinins have been described in Salmonella spp. $(14,19,26)$, but they are mannoseresistant and hence different from the mannose-sensitive hemagglutinin identified here.

Many enteropathogenic bacteria have well-characterized hemagglutinating properties which are indicative of an ability to adhere to intestinal mucosal surfaces $(11,13,15)$. Correlation between hemagglutination, adhesion and bacterial pathogenicity have been demonstrated $(2,3,8,9)$. In $S$. Enteritidis, several fimbrial hemagglutinins have been implicated in bacterial attachment, colonization and pathogenicity. SEF14 has been shown to contribute to bacterial adherence to mouse epithelial cells and to chicken ovarian granulosa cells $(20,28)$. In addition, SEF 14 may be required for systemic infections $(8,21)$. Aslanzadeh and Paulissen $(2,3)$ demonstrated a role for SEF21 fimbriae (type 1 fimbriae) in the in vitro adhesion of $S$. Enteritidis to mouse intestinal epithelial cells. Jones and Richardson (14) associated a nonfimbrial mannose-resistant hemagglutinin with adhesion of $S$. Typhimurium to HeLa cells. In contrast, other studies have failed to demonstrate a role for fimbrial and nonfimbrial hemagglutinins in the adherence of $S$. Enteritidis and $S$. Typhimurium, respectively $(1,21,22,26,30)$.

Our findings indicate that $S$. Enteritidis produces a nonfimbrial mannose-sensitive hemagglutinin. Further studies of this hemagglutinin, as its purification and characterization and studies to correlate it with attachment to epithelial cell lines are being carried out to determine the possible role of this putative adhesin in salmonellosis.

\section{ACKNOWLEDGEMENTS}

We are grateful to FAPESP for financial support to this work - grant n ${ }^{\circ}$ 97/12797-6.

\section{RESUMO}

\section{Propriedades hemaglutinantes de Salmonella enterica sorotipo Enteritidis isoladas de diferentes fontes}

Foram estudadas 25 amostras de Salmonella enterica sorotipo Enteritidis isoladas de diferentes fontes, em testes de hemaglutinação. Amostras bacterianas cultivadas em diferentes meios de cultura causavam hemaglutinação na presença de hemácias humanas, entretanto, não foi observada reação com hemácias de outras espécies. A expressão da atividade hemaglutinante foi melhor em ágar CFA a $37^{\circ} \mathrm{C}$. A hemaglutinação foi inibida por D-manose, D-manitol, melibiose, D-rafinose, Lramnose e sacarose. A análise ultraestrutural não revelou a presença de estruturas filamentosas na superfície bacteriana, sugerindo que a hemaglutinina de Salmonella Enteritidis seja de natureza não fimbrial. Os dados sugerem que Salmonella 
Enteritidis produz uma hemaglutinina não fimbrial manosesensível, específica para hemácias humanas, que pode ser extraída na forma solúvel.

Palavras-chave: Salmonella Enteritidis, atividade hemaglutinante, hemaglutinina manose-sensível, hemaglutinina não fimbrial

\section{REFERENCES}

1. Allen-Vercoe, E.; Woodward, M.J. The role of flagella, but not fimbriae, in the adherence of Salmonella enterica serotype Enteritidis to chick gut explant. J. Med. Microbiol., 48: 771-780, 1999.

2. Aslanzadeh, J.; Paulissen, L.J. Adherence and pathogenesis of Salmonella enteritidis in mice. Microbiol. Immunol., 34: 885-893, 1990.

3. Aslanzadeh, J.; Paulissen, L.J. Role of type 1 and 3 fimbriae on the adherence and pathogenesis of Salmonella enteritidis in mice. Microbiol. Immunol., 36: 351-359, 1992.

4. Barrow, P.A. Virulence of Salmonella enterica serovar Enteritidis In: Saeed, A.M.; Gast, R.K.; Potter, M.E.; Wall, P.G. (eds.), Salmonella enterica serovar Enteritidis in humans and animals, Ames: Iowa State University Press, 1999, p.173-182.

5. Camargo, Z.P.; Taborda, C.P.; Rodrigues, E.G.; Travassos, L.R. The use of cell-free antigens of Paracoccidioides brasiliensis in serological tests. J. Med. Vet. Mycol., 29: 31-38, 1991.

6. Collazo, C.M.; Galán, J.E. The invasion-associated type-III protein secretion system in Salmonella - a rewiew. Gene, 192: 51-59, 1997.

7. Dibb-Fuller, M.; Allen-Vercoe, E.; Woodward, M.J.; Thorns, C.J. Expression of SEF17 fimbriae by Salmonella serotype Enteritidis. Lett. Appl. Microbiol., 25: 447-452, 1997.

8. Edwards, R.A.; Schifferli, D.M.; Maloy, S.R. A role of Salmonella fimbriae in intraperitoneal infections. PNAS. 97: 1258-1262, 2000.

9. Ewen, S.W.B.; Naughton, P.J.; Grant, G. Salmonella enterica var Typhimurium and Salmonella enterica var Enteritidis express type 1 fimbriae in the rat in vivo. FEMS Immunol. Med. Microbiol., 18: 185-192, 1997.

10. Feutrier, J.; Kay, W.W.; Trust, T.J. Purification and characterization of fimbriae from Salmonella enteritidis. J. Bacteriol., 168: 221-227, 1986.

11. Gilboa-Garber, N.; Avichezer, D.; Garber, N.C. Bacterial lectins: properties, structure, effects, function and applications. In: Gabius, H.J.; Gabius, S. (eds.), Glycosciences. Chapman \& Hall, London, 1997, p.369-398.

12. Ginocchio, C.C.; Olmsted, S.B.; Wells, C.L.; Galán, J.E. Contact with epithelial cells induces the formation of surface appendages on Salmonella typhimurium. Cell, 76:717-724, 1994.

13. Goldhar, J. Bacterial lectinlike adhesins: determination and specificity. Methods Enzymol., 236: 211-229, 1994.

14. Jones, G.W.; Richardson, L.A. The attachment to, and invasion of HeLa cells by Salmonella typhimurium: the contribution of mannosesensitive and mannose-resistant haemagglutinating activities. J. Gen. Microbiol., 127: 361-370, 1981.

15. Klemm, P.; Schembri, M.A.S. Bacterial adhesins: function and structure. Int. J. Med. Microbiol., 290: 27-35, 2000.

16. Korhonen, T.K.; Lounatmaa, K.; Ranta, H.; Kuusi, N. Characterization of type 1 pili of Salmonella typhimurium LT2. J. Bacteriol., 144: 800-805, 1980.

17. Lacey, R.W. Food-borne bacterial infections. Parasitology, 107: 575593, 1993.

18. Old, D.C. Inhibition of the interaction between fimbrial haemagglutinins and erythrocytes by D-mannose and other carbohydrates. J. Gen. Microbiol., 71: 149-157, 1972.
19. Old, D.C.; Tavendale, A. Adhesion of Salmonella dublin to HEp-2 epithelial cells. Lett. Appl. Microbiol., 3: 73-76, 1986.

20. Peralta, R.; Yokoyama, H.; Ikemori, Y.; Kuroki, M.; Kodama, Y. Passive immunisation against experimental salmonellosis in mice by orally administered hen egg-yolk antibodies especific for $14-\mathrm{kDa}$ fimbriae of Salmonella enteritidis. J. Med. Microbiol., 118: 145146, 1994.

21. Rajashekara, G.; Munir, S.; Alexeyev, M.F.; Halvorson, D.A.; Wells, C.L.; Nagaraja, K.V. Pathogenic role of a SEF14, SEF17, and SEF21 Fimbriae in Salmonella enterica Serovar Enteritidis infection of chickens. Appl. Environ. Microbiol., 66: 1759-1763, 2000.

22. Robertson, J.M.C.; Grant, G.; Allen-Vercoe, E.; Woodward, M.J.; Pusztai, A.; Flint, H.J. Adhesion of Salmonella enterica var Enteritidis strains lacking fimbriae and flagella to rat ileal explants cultured at the air interface or submerged in tissue culture medium. J. Med. Microbiol., 49: 691-696, 2000.

23. Rodrigue, D.C.; Tauxe, R.V.; Rowe, B. International increase in Salmonella enteritidis: a new pandemic? Epidemiol. Infect., 105: 21-27, 1990.

24. Sojka, M.G.; Carter, M.A.; Thorns, C.J. Characterization of epitopes of type 1 fimbriae of Salmonella using monoclonal antibodies specific for SEF21 fimbriae of Salmonella enteritidis. Vet. Microbiol., 59: 157-174, 1998

25. Tavechio, A.T.; Fernandes, S.A.; Neves, B.C.; Dias, A.M.G.; Irino, K. Changing patterns of Salmonella serovars: increase of Salmonella enteritidis in São Paulo, Brasil. Rev. Inst. Med. Trop., 38: 315-322, 1996.

26. Tavendale, A.; Jardine, C.K.H.; Old, D.C.; Duguid, J.P. Haemagglutinins and adhesion of Salmonella typhimurium to HEp2 and HeLa cells. J. Med. Microbiol., 16: 271-380, 1983.

27. Thankavel, K.; Shah, A.H.; Cohen, M.S.; Ikeda, T.; Lorenz, R.G.; Curtiss, R.; Abraham, S.N. Molecular basis for the enterocyte tropism exhibited by Salmonella typhimurium type 1 fimbriae. J. Biol. Chem., 274: 5797-5809, 1999.

28. Thiagarajan, D.; Saeed, M.; Turek, J.; Asim, E. In vitro attachment and invasion of chicken ovarian granulosa cells by Salmonella enteritidis phage type 8. Infect. Immun., 64: 5015-5021, 1996.

29. Thorns, C.J.; Sojka, M.G.; Mclaren, I.M.; Dibb-Fuller, M. Characterization of monoclonal antibodies against a fimbrial structure of Salmonella enteritidis and certain other serogroup D salmonellae and their application as serotyping reagents. Res. Vet. Sci., 53: 300308, 1992.

30. Thorns, C.J.; Turcotte, C.; Gemmell, C.G.; Woodward, M.J. Studies into the role of the SEF14 fimbrial antigen in the pathogenesis of Salmonella enteritidis. Microb. Pathog., 20: 235-246, 1996.

31. Walker, S.L.; Sojka, M.; Dibb-Fuller. M.; Woodward, M.J. Effect of $\mathrm{pH}$, temperature and surface contact on the elaboration of fimbriae and flagella by Salmonella serotype Enteritidis. J. Med. Microbiol., 48: 353-261, 1999.

32. Williams, P.H.; Knutton, S.; Brown, M.G.M.; Candy, D.C.A.; McNeish, A.S. Characterization of nonfimbrial mannose-resistant protein hemagglutininins of two Escherichia coli strains isolated from infants with enteritis. Infect. Immun., 44: 592-598, 1984.

33. Woodward, M.J.; Sojka, M.; Springings, K.A.; Humphrey, T.J. The role of SEF14 and SEF17 fimbriae in the adherence of Salmonella enterica serotype Enteritidis to inanimate surfaces. J. Med. Microbiol., 49: 481-487, 2000.

34. Yano, T.; Catani, C.F.; Arita, M.; Honda, T.; Miwatani, T. Purification and partial characterization of a hemagglutinating factor (HAF): a possible adhesive factor of the diffuse adherent Escherichia coli (DAEC). Rev. Inst. Med. Trop., 38: 401-406, 1996.

35. Zierler, M.K.; Galán, J.E. Contact with cultures epithelial cells stimulates Secretion of Salmonella typhimurium invasion protein InvJ. Infect. Immun., 63: 4024-4028, 1995. 